\title{
Fractura patológica de la mandíbula asociada a quiste radicular. Reporte de 3 casos clínicos
}

\author{
Mandibular pathologic fracture associated with radicular cyst. \\ Report of three clinical cases
}

J. Bouguila', L. Córdova Jara², I. Zairi', A. Adouani'

Resumen: Introducción. El quiste radicular es el quiste más común de los maxilares. Su tamaño puede variar desde una lesión que abarca el proceso alveolar hasta uno extenso que oblitera el espacio antral maxilar o causa una fractura patológica mandibular.

Reporte de casos. Se reportan tres casos con fractura patológica mandibular asociados a quiste radicular ocurridos después de trauma facial. El diagnóstico fue sugerido por un estudio clínico, radiografía panorámica y confirmado por el estudio histopatológico de la pieza operatoria. El tratamiento consistió en enucleación quística seguido por inmovilización de fragmentos con osteosíntesis o bloqueo intermaxilar. El resultado clínico y radiológico a corto plazo fue favorable.

Discusión. Se discuten aspectos propios de la patología y su terapia. Conclusión. El éxito del tratamiento depende de una adecuada terapia en que sus principios más importantes son la remoción de la lesión mediante enucleación y una fijación estable.

Palabras clave: Quiste radicular; Fractura patológica; Mandíbula.

Recibido: 29.02 .08

Aceptado: 16.06 .08
Abstract: Introduction. Radicular cyst is the most common cyst of the oral cavity. It may range in size from a small periapical lesion to one that can obliterate the antral space or cause mandibular fracture.

Case reports. We report three cases of radicular cyst complicated by mandibular fracture that occurred after maxillofacial trauma. The diagnosis was strongly suggested by panoramic radiography and confirmed by pathology examination of the operative specimen. Treatment consisted in cyst enucleation followed by immobilization of fragments by osteosynthesis or maxillomandibular fixation. The clinical and radiologic outcome was favorable.

Discussion. The particularities and treatment are discussed. Conclusion. Treatment success is dependent on adequate therapy, the principles of which are removing the lesion and providing stable fixation.

Key words: Radicular cyst; Pathologic fracture; Mandible.
1 Servicio de Cirugía Plástica y Máxilo Facial, Hospital Charles Nicolle, Tunis, Tunez

2 Equipo de Cirugía Oral y Máxilo Facial. Hospital San José, Santiago de Chile. Facultad de Odontología Universidad de Chile. Santiago de Chile. Chile

\section{Correspondencia:}

Dr. L. Córdova Jara

Facultad de Odontología. Universidad de Chile

Calle Olivos 943, Independencia, Santiago de Chile.

Email: luiscordovajara@vtr.net 


\section{Introducción}

La fractura mandibular es una de las lesiones traumáticas más frecuentes ocurridas en el territorio máxilo facial, ${ }^{1}$ y el quiste radicular es una de las lesiones odontogénicas más comunes en los maxilares. La existencia de ambas ocurre esporádicamente.

Se realizó un estudio de datos en los archivos del departamento de Cirugía Plástica y Máxilo Facial del Hospital Charles Nicolle (Tunisía, Tunez) en un período de 10 años (1995 a 2004) que cumpliera con el criterio de: fractura patológica mandibular asociadas a la presencia de quiste radicular local. De un total de 1.100 fracturas faciales, se encontraron $3(0,27 \%)$ :

Se presentan tres casos clínicos y se discute su tratamiento.

\section{Casos clínicos}

\section{Caso 1}

Varón de 18 años atendido luego de trauma facial por violencia, presentó dolor y aumento de volumen en la región mentoniana. La imagen radiográfica mostró una fractura sinfisiaria a través de una lesión radio lúcida periapical (Fig. 1).

El paciente fue tratado con enucleación del quiste e inmovilización de fragmentos por bloqueo intermaxilar (Figs. 2 y 3) y terapia endodóntica posterior a la intervención. El estudio histopatológico comprobó el diagnóstico de quiste radicular. La radiografía panorámica realizada a un mes de post operatorio, evidenció la evolución favorable de ambas lesiones.

\section{Caso 2}

Varón de 40 años ingresado con fractura de ángulo mandibular izquierdo y cuerpo mandibular derecho asociada a una larga lesión radiolúcida (Fig. 4). Esta fue enucleada por vía intraoral al igual que las raíces dentarias asociadas, seguido de estabilización de fragmentos mediante bloqueo intermaxilar utilizando ligaduras Ivy (Fig. 5). La histología confirmó su naturaleza de quiste radicular.

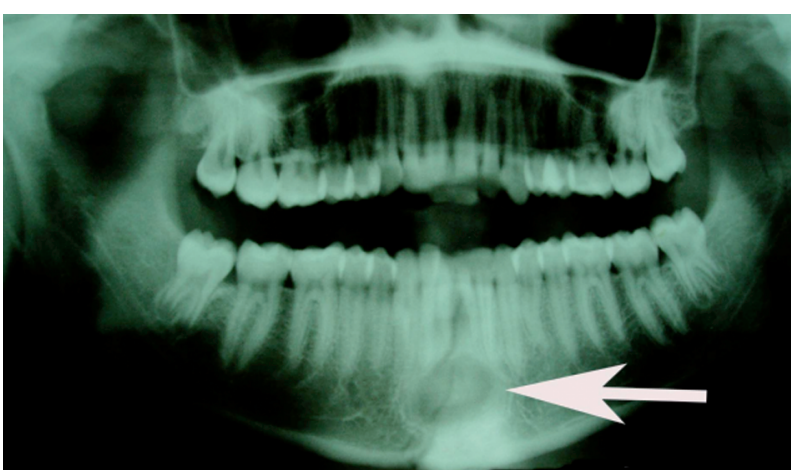

Figura 1. Radiografía panorámica mostrando el área radio úcida y la fractura sinfisiaria (flecha).

Figure 1. Panoramic radiography showing the radiolucent area and the symphyseal fracture (arrow).

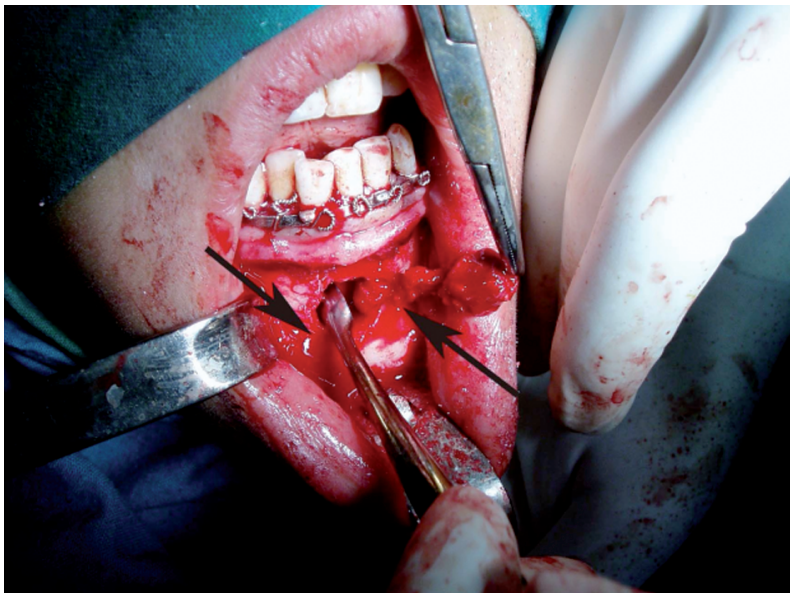

Figura 2. Vista intra operatoria de la enucleación del quiste. Figure 2. Intraoperative view of cyst enucleation.

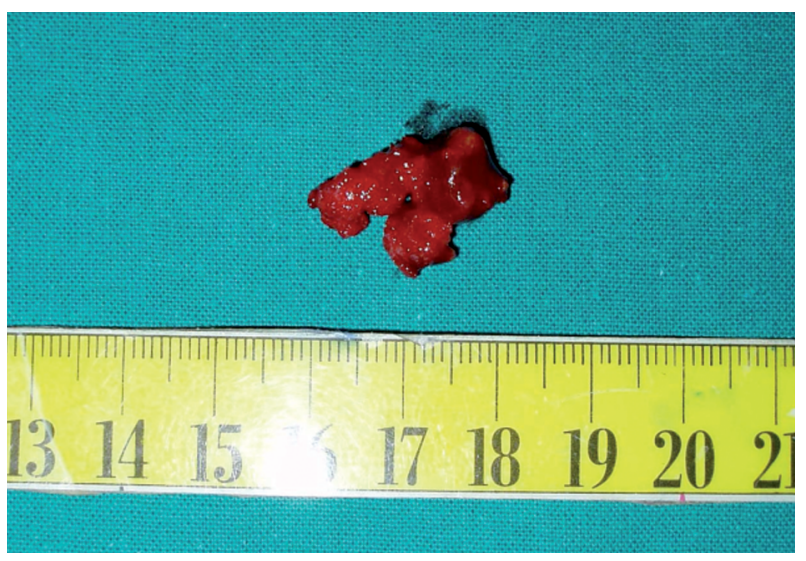

Figura 3. La pieza operatoria.

Figure 3. Operative specimen.

\section{Introduction}

Mandibular fracture is one of the most common traumatic injuries in the maxillofacial territory' and radicular cyst is one of the most common odontogenic jaw lesions. Both lesions occur sporadically.

A study was made of the data in the archives of the Plastic and Maxillofacial Surgery Department of Charles Nicolle Hospital (Tunis, Tunisia) from a 10 year period (1995 to 2004) that satisfied the criterion of: mandibular pathologic fracture associated with the presence of local radicular cyst. Out of a total of 1100 facial fractures, 3 (0.27\%) fractures met these conditions.

The three clinical cases are reported and their treatment is discussed.

\section{Clinical case}

\section{Case 1}

An 18-year-old man was seen for facial trauma due to violence. He presented pain and a swollen chin area. The radiographic image revealed a symphyseal fracture that intersected a periapical radiolucent lesion (Fig. 1).

The patient was treated by cyst enucleation and immobilization of the fragments by maxillomandibular fixation (Figs. 2 and 3). He later underwent root canal. Histopathologic study verified the diagnosis of radicular cyst. Panoramic radiography performed one month after surgery demonstrated the favorable evolution of both lesions.

\section{Case 2}

A 40-year-old man was hospitalized for fracture of the left mandibular angle and right mandibular body associat- 


\section{Caso 3}

Varón de 44 años ingresado por trauma facial. El estudio radiográfico reveló una gran lesión radiolúcida y una fractura del ángulo desplazada (Fig. 6).

Se realizó enucleación de la lesión, extracción de las raíces dentarias causantes y la reducción-osteosíntesis de la fractura con alambre intraóseo y mini placa con tornillos monocorticales (Fig. 7).

El estudio histológico del material enucleado, reveló un quiste radicular inflamatorio. La consolidación ósea fue observada radiográficamente dos meses después.

\section{Discusión}

Una fractura ósea, es una discontinuidad completa o parcial de un hueso causada por fuerzas directas o indirectas. ${ }^{2}$ Una fractura patológica de la mandíbula se define como una fractura causada por una patología ósea previa, y su incidencia es menor al $2 \%$ de todas las fracturas faciales. ${ }^{1}$ La patogenia de la fractura patológica no es del todo clara, pero algunos autores hablan de trauma mínimo o inadecuado que causa una fractura en una lesión ósea preexistente. Sin embargo, es difícil la cuantificación del trauma mínimo necesario por medios científicos. ${ }^{2}$ La mayoría de las fracturas patológicas reportadas en la literatura se asocian a osteorradionecrosis o lesiones malignas orales. ${ }^{1,2}$

La fractura patológica causada por un quiste radicular ocurre raramente. En los últimos 50 años, 2,4 se han publicado escasos reportes sobre el tema, la mayoría casos individuales. El primero fue descrito por Mardsen, ${ }^{3}$ en 1964 y en 1974 lo hizo Schegg. ${ }^{4}$ Ezsias y Sugar, ${ }^{2}$ reportaron dos casos que fueron tratados con reducción abierta usando placas de reconstrucción para dar continuidad a la mandíbula. Gerhards, ${ }^{1}$ publicó tres casos de fracturas causadas por quistes odontogénicos subyacentes (dos quistes radiculares y uno folicular) tratados con reducción abierta, miniplacas y tornillos monocorticales.

Es particularmente interesante que lesiones con alta incidencia (63-78\% de todos los quistes de los maxilares) ${ }^{5,6}$ causen fracturas

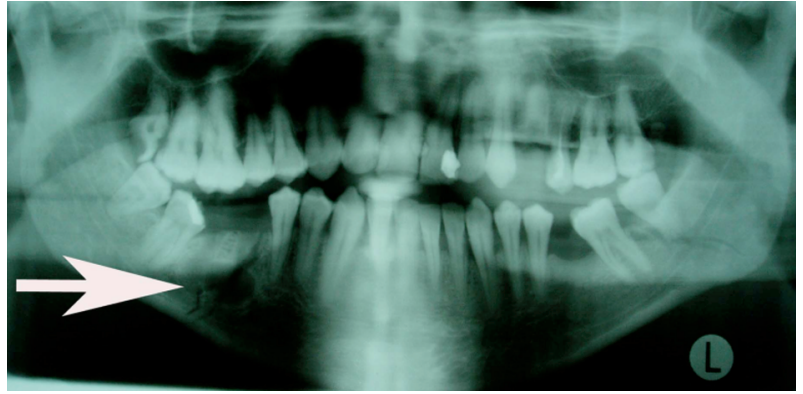

Figura 4. Radiografía panorámica mostrando la fractura de ángulo izquierdo y una fractura del cuerpo derecha a través de la lesión radiolúcida (flecha).

Figure 4. Panoramic radiography showing the left angle fracture and a right body fracture through a radiolucent lesion (arrow).

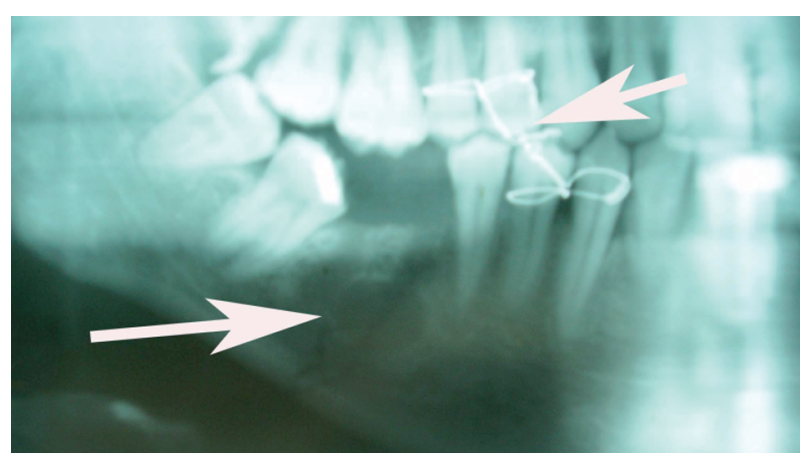

Figura 5. Fijación intermaxilar usando ligadura Ivy (flecha superior) y lesión radiolúcida mandibular (flecha inferior).

Figure 5. Maxillomandibular fixation using Ivy loops (upper arrow) and mandibular radiolucent lesion (lower arrow).

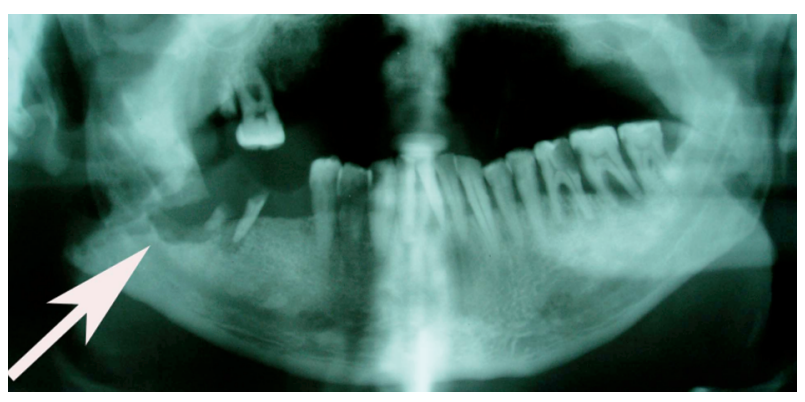

Figura 6. Radiografía panorámica mostrando una lesión radio lúcida extensa (flecha) y la fractura de ángulo desplazada.

Figure 6. Panoramic radiography showing an extensive radiolucent lesion (arrow) and the displaced angle fracture. ed with a large radiolucent lesion (Fig. 4). The radiolucent lesion was enucleated with the associated dental roots using an intraoral approach. The fragments were stabilized by maxillomandibular fixation using Ivy loops (Fig. 5). The histology confirmed its nature as a radicular cyst.

\section{Case 3}

A 44-year-old man was admitted for facial trauma. The radiographic study revealed a large radiolucent lesion and a fracture of the angle with displacement (Fig. 6).

Enucleation of the lesion, extraction of the causal dental roots, and reduction-osteosynthesis of the fracture were performed with intraosseous wires and a miniplate with monocortical screws (Fig. 7).

Histologic study of the enucleated material revealed an inflammatory radicular cyst. Bone consolidation was confirmed radiographically two months later.

\section{Discussion}

A bone fracture is a complete or partial discontinuity in a bone caused by direct or indirect forces. ${ }^{2}$ Pathologic fracture is defined as a fracture caused by the presence of previous bone pathology, in this case, of the mandible. Its incidence is less than $2 \%$ of all facial fractures. ${ }^{1}$ The pathogenesis of pathologic fracture is not absolutely clear, but some authors postulate minimum or inadequate trauma that causes fracture on a pre-existent bone lesion. However, it is difficult to quantify the minimum trauma necessary by scientific means. ${ }^{2}$ Most pathologic fractures reported in the literature are associated with osteoradionecrosis or oral malignant lesions. ${ }^{1,2}$

Pathologic fracture caused by radicular cyst is rare. In the last 50 years, 2,4 few reports have been published on the 
tan esporádicamente. La mayoría de las fracturas ocurren durante la masticación o cuando el paciente sufre un accidente. ${ }^{1}$ En nuestros casos, las fracturas son secundarias a trauma por violencia.

Las fracturas patológicas de la mandíbula asociadas a un quiste radicular deben ser tratadas con la eliminación de la causa o condición primaria y mediante inmovilización de los fragmentos a través de osteosíntesis, arcos y fijación intermaxilar.1,2

Los tratamientos recomendados para lesiones quísticas radiculares incluyen la enucleación, curetaje, marsupialización y ocasionalmente la resección mandibular segmentaria. 1,2,6,7 La marsupialización (Sakkas \& Pogrel) 8 reduciría la frecuencia de fractura patológica mandibular o discontinuidad ósea. Sin embargo, la desventaja de esta técnica es el largo tiempo que requiere para ser exitoso, lo que la limita sólo a pacientes capacitados para hacerlo. ${ }^{6,8} \mathrm{El}$ tratamiento mediante enucleación fue propuesto en otros estudios. ${ }^{6}$ La cavidad quística es generalmente repletada con gasa yodoformada que aporta condiciones favorables para la epitelización. Se ha visto que no existe recurrencia mediante la enucleación lo que indicaría que la resección no es necesaria, a

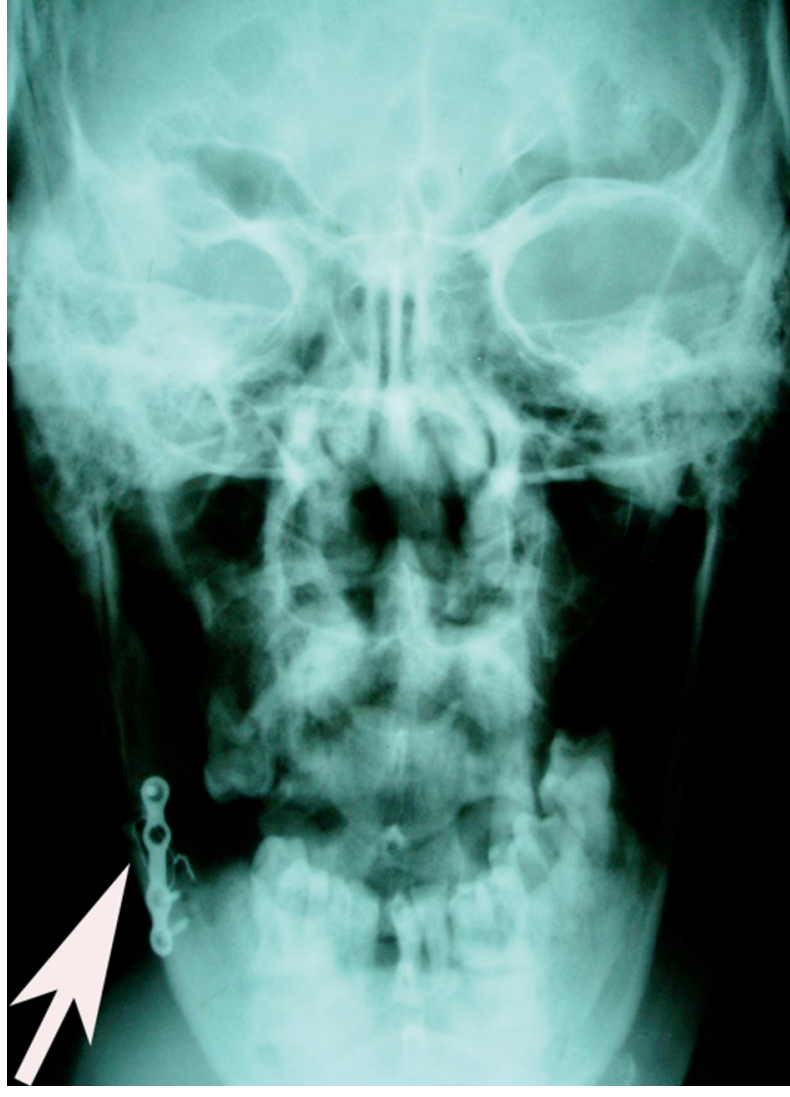

Figura 7. Fijación de la fractura mediante un alambre intraóseo y una mini placa con tornillos monocorticales (flecha).

Figure 7. Fracture fixation using intraosseous wires and a miniplate with monocortical screws (arrow). topic. Most have been reports of individual cases. The first was described by Mardsen ${ }^{3}$ in 1964; Schegg 4 reported another in 1974. Ezsias and Sugar ${ }^{2}$ reported two cases that were treated by open reduction using reconstruction plates to give continuity to the mandible. Gerhards ${ }^{1}$ published three cases of fractures caused by underlying odontogenic cysts (two radicular cysts and a follicular cyst), which were treated by open reduction, miniplates, and monocortical screws.

It is particularly interesting that lesions that have a high incidence (63-78\% of all jaw cysts) $)^{5,6}$ cause fractures so sporadically. Most of the fractures occur during mastication or when the patient suffers an accident. ${ }^{1}$ In our cases, the fractures were secondary to violent injury.

Mandibular pathologic fracture associated with radicular cyst must be treated by eliminating the cause, or primary condition, and immobilizing the fragments by osteosynthesis, plates, and maxillomandibular fixation.1,2

The recommended treatments for radicular cystic lesions include enucleation, curettage, marsupialization, and, occasionally, segmental mandibular resection. 1,2,6,7 Marsupialization (Sakkas \& Pogrel) ${ }^{8}$ reduces the frequency of mandibular pathologic fracture or bone discontinuity. Nevertheless, the disadvantage of this technique is the long time required for success, which limits its use to patients capable of undergoing the procedure. ${ }^{6,8}$ Enucleation therapy has been proposed in other studies. ${ }^{6}$ The cystic cavity generally is filled with iodine-soaked gauze, which creates favorable conditions for epithelization. It has been seen that there is no recurrence with enucleation, which may indicate that resection is not necessary, as long as access is adequate and the lesion can be completely enucleated. The causal tooth must be treated and the therapy given will depend on the degree of damage, the location, relation with the fracture seam, etc. Histopathologic examination of the material removed is obligatory, this being the most specific method for establishing the diagnosis of radicular cyst.2,6 The time for bone healing may be longer, ${ }^{2}$ but in the cases reported 
5. Takiguchi M, Fujiwara T, Sobue S, Ooshima T. Radicular cyst associated with a primary molar following pulp therapy: a case report. Int J Paediatr Dent 2001; 11:452-5.

6. Maksoud C, Piral T, G. Princ G, A G. Découverte fortuite d'un volumineux kyste mandibulaire chez un enfant. Arch Pédiatr 2002;9:598-601.

7. Matise JL, Beto LM, Fantasia JE, AF F. Pathologic fracture of the mandible associated with simultaneous occurrence of odontogenic keratocyst and traumatic bone cyst. J Oral Maxillofac Surg 1987;45:69-71.

8. Pogrel MA. Treatment of keratocysts: the case of decompression and marsupialization. J Oral Maxillofac Surg 2005;63:1667-73. here, an acceptable result was obtained in the usual times. Regular radiologic clinical monitoring is necessary to achieve complete bone regeneration. Therapeutic success depends on proper therapy, the most important principles of which are removal of the lesion by enucleation, treatment of the causal tooth, and supplying stable fixation. 